The Geographical Journal of Nepal

Vol. 10: 73-88, 2017

Central Department of Geography,

Tribhuvan University, Kathmandu, Nepal

\title{
Livelihood and coping strategies among urban poor people in post-conflict period: Case of the Kathmandu, Nepal
}

\author{
Kedar Dahal \\ Department of Geography, Tri-Chandra Multiple Campus, Tribhuvan Univerity, \\ Kathmandu, Nepal \\ Email: kedar.geog@gmail.com
}

Kathmandu is receiving large number of poor immigrants from the neighbouring districts. Many of them are living in the temporary or semi-permanent structure of dwelling on the bank of the river Bagmati and its tributaries. A traumatic experience of an unprecedented decade long armed conflict in Nepal between government security force and Maoist insurgents between 1996-2005 forced people migrate to the safer zones for their livelihood security, particularly in the urban areas like Kathmandu. As a consequence an increase in landlessness, joblessness, homelessness, livelihood insecurity, and disruption of the social fabric have been noticed. Now the country is in the post-conflict phase. This study, therefore, seeks to explore coping strategies of the poor people residing in Kathmandu in post-conflict phase by using primary data collected from sampled household based on multi-stage sampling procedures. Livelihood of the poor people is highly influenced by the armed conflict in the past. But the postconflict phase is characterized by increasing mobility, expanding knowledge and opportunities. Working farther from the place of residence, change in food habits, mutual cooperation and borrowing are important coping strategies adopted by the poor people living in the poverty pockets.

Keywords: Conflict; post-conflict; livelihood; urban poor; coping strategies; Kathmandu city. 


\section{Introduction}

The term 'conflict' is simply defined as an activity for political stress, instability and violence, leading to physical damages, psychological fear, death and deprivation. Conflict and political instability are often combined with a high susceptibility to violence, forced displacement, the denial of basic human rights, the deliberate destruction of livelihood and the incidence of serious poverty (Schafer, 2002). Conflict creates an insecurity perception which shapes the migration process as a whole (Sirkeci, 2009). Earlier studies have shown that conflict and violence have led to widespread asset depletion, displacement, increased levels of debt, blocked access and disintegration of markets, a politicization of ethnicity or the abandonment of traditional livelihood strategies (Jaspars\&Shoham, 2002 cited in Schutte, 2006). Studies carried out in Afghanistan and other countries show that chronic conflict and political instability decisively influence livelihood strategies of the urban poor, and that increasing levels of risk and constant uncertainty most probably lead to a change of livelihood system (Pain\&Lautze, 2002; Schutte, 2006).

Nepal has been suffering from political instability and conflict since 1989/1990, when the people's movement for the restoration of democracy started. Chronology of political events shows that not a single political party was able to complete its five-year term in the government. The situation has been getting worse especially after 1996, when the Maoists started their armed conflict in the rural areas in the name of Janayuddha (People's War). Within a decade of conflict, many lives and properties were lost; which, in fact, brought many changes in the perception, security and livelihood of the people both in rural as well as in urban areas; and generated fear, tension and insecurity. This period of time, generally ended in 2005, is known as conflict period. After the peace deal in November 2005, which is, in this study, known as 'post-conflict phase'.

Conflict in Nepal is only a part of politics, and result of poverty, social exclusion, deprivation and discrimination. Due to internal conflict, large numbers of people have been displaced and have migrated to urban areas including Kathmandu in recent years after 1995 for securing their livelihood. The armed conflict and violence have left various impacts on the sources of livelihood and income of poor people. Some of the examples of impacts created by conflict are:(i) undermining food security by blocking the movement of goods, services and people; (ii) travelling of young people outside the village to get alternative employment rather than to join in the Janasena (People's Liberation Army); (iii) reducing non-farming employment opportunities in villages; (iv) shifting of financial resources from basic service sector to unproductive 
military expenditure; and (v) increasing pressure for pro-poor to a change in the rules and practice in natural resource use (Seddon \& Hussein, 2002; Upreti, 2004; B.K et al., 2009). One of the major impact of conflict was the migration of the (poor) people of rural areas into an urban center. Being the capital city, Kathmandu attracted many people to live and work; and these migrated people have adopted different measures to maintain their livelihood. This study, therefore, seeks to explore the coping strategies of the poor people residing in Kathmandu in post-conflict phase of the country.

\section{Study area}

Kathmandu Metropolitan City has been taken into consideration for the present study (Figure 1). It is only one metropolitan city of Nepal, designated in 1995, covers only $50.63 \mathrm{~km}^{2}$ of land. Kathmandu, a primate city, ranks the largest among the cities of Nepal; and among the oldest settlement in the central Himalaya, situated in a valley in the Himalayan foothills at an altitude of 1,350 meters above mean sea level.Due to the concentration of services and facilities, Kathmandu, at present, is attracting many people from different parts of the country.Kathmandu has highest share of urban population in the country.

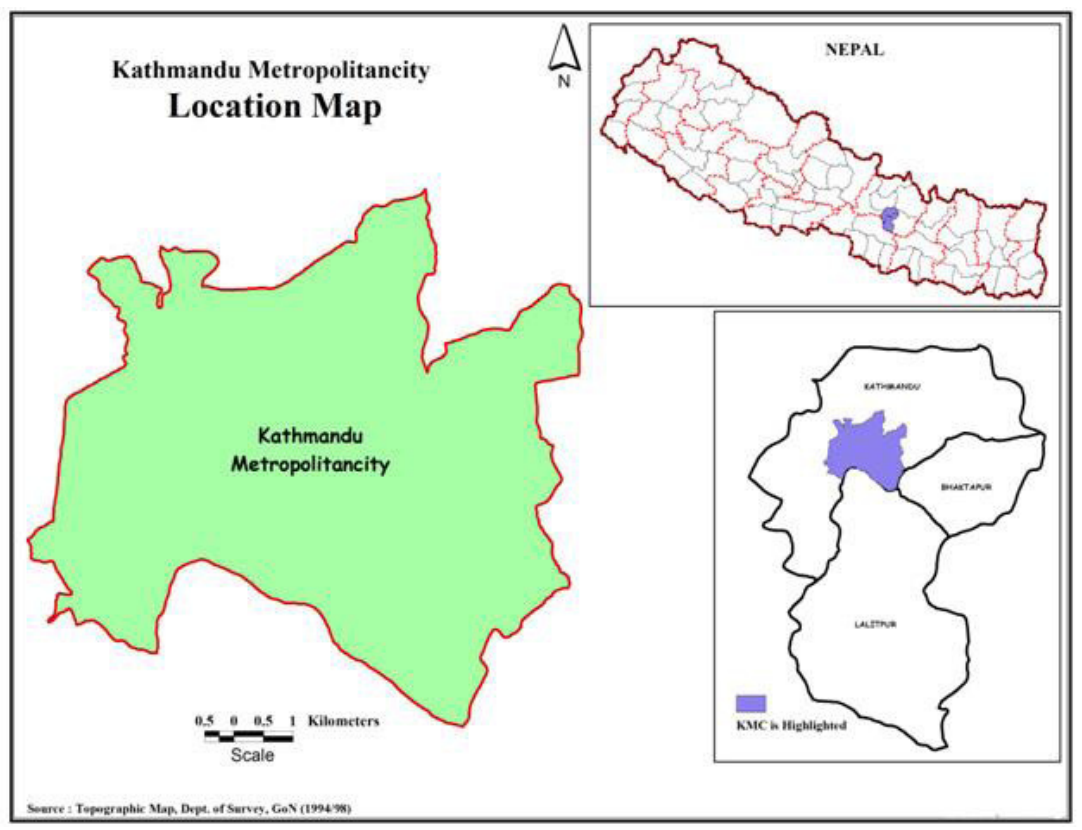

Figure 1. Study area 
Urban poverty is increasing at high pace particularly in the Kathmandu Metropolitan City (Dahal, 2012).During a decade long political turmoil in the country, many poor communities have chosen Kathmandu as a best destination for securing their lives and properties. They are concentrated either on the bank of rivers or in the open space near the historical and religious monuments. There are altogether 34 locations, where poor people are concentrated in Kathmandu; and these areas where poor are concentrated are termed as 'poverty pockets' as the term used by Diana (2004) ${ }^{1}$. These poverty pockets are characterized by a mosaic of people in terms of age, gender, economic activities, culture etc.

\section{Methodology}

Pockets of poverty are developed randomly in the different corners of the Kathmandu Metropolitan City where poor slum dwellers and squatters have built a unique landscape in the city. Among 34 poverty pockets, $50 \%$ were randomly selected for the study. The entire analysis is based on the data and information gathered during the period between June-August 2009 from the sample poverty clusters and households; and later again verify the data through selected household in June 2013.

A multi-stage sampling framework was used in this study. According to this framework, the study area is divided into different zones: central, middle and periphery. There are 10 poverty pockets, which belong to the central zone, 16 in middle and 8 poverty pockets are in periphery zone in Kathmandu (Figure 2).

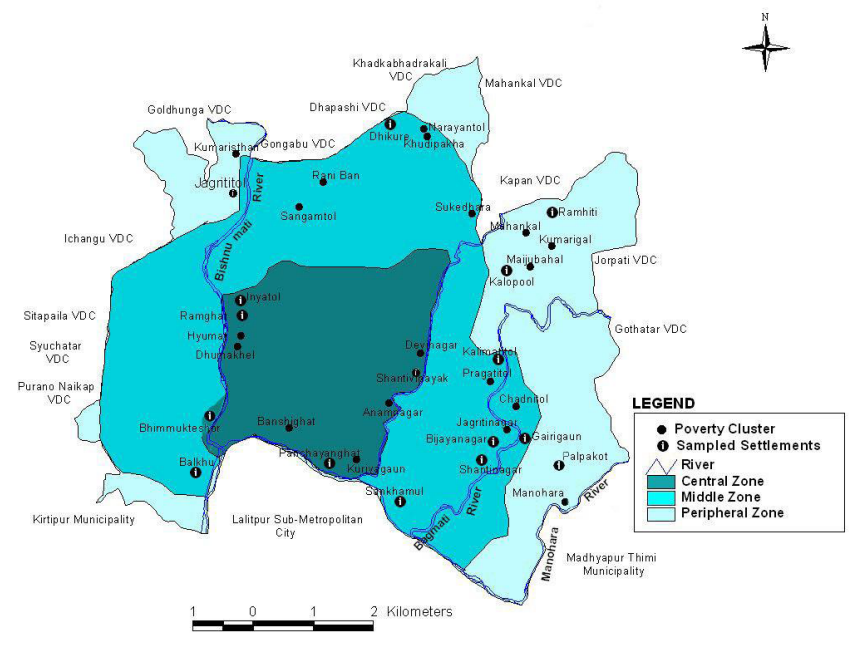

Figure 2. Distribution of poverty pockets in Kathmandu \|76 
Out of the total households in the sampled poverty pockets, only $20 \%$ were chosen from each stratum for the study purpose. Detail of methods of data collection is summarized in Table 1.

Table1. List of sampled poverty pockets, types of survey and sample size

\begin{tabular}{|c|c|c|c|c|}
\hline \multirow{2}{*}{$\begin{array}{l}\text { Stratum/ } \\
\text { Zones }\end{array}$} & \multirow{2}{*}{$\begin{array}{l}\text { Poverty Pockets/ } \\
\text { Location }\end{array}$} & \multirow{2}{*}{$\begin{array}{l}\text { Types of Survey } \\
\text { Carried out }\end{array}$} & \multicolumn{2}{|c|}{ Household Sample Survey } \\
\hline & & & Total HHs & Sampled HHS \\
\hline \multirow{5}{*}{ Central } & Bhimmukteshwor & $\mathrm{HH}$ & 33 & 7 \\
\hline & Inyatol & $\mathrm{HH}, \mathrm{KII}$ & 34 & 7 \\
\hline & Panchayanghat & HH, FDG, KII, CS & 250 & 50 \\
\hline & Ramghat & HH, KII & 20 & 4 \\
\hline & Shantibinayak & $\mathrm{HH}, \mathrm{KII}$ & 42 & 8 \\
\hline \multicolumn{3}{|l|}{ Sub-total } & 379 & 76 \\
\hline \multirow{8}{*}{ Middle } & Balkhu & HH, FGD, KII, CS & 300 & 60 \\
\hline & Bijayanagar & $\mathrm{HH}$ & 25 & 5 \\
\hline & Dhikure & $\mathrm{HH}, \mathrm{KII}$ & 26 & 5 \\
\hline & Gairigaun & HH, FGD & 45 & 9 \\
\hline & Kalimatidol & $\mathrm{HH}$ & 16 & 3 \\
\hline & Narayantol & HH,FGD & 30 & 6 \\
\hline & Shankhamul & $\mathrm{HH}, \mathrm{KII}$ & 106 & 21 \\
\hline & Shantinagar & $\mathrm{HH}, \mathrm{KII}, \mathrm{CS}$ & 358 & 72 \\
\hline \multicolumn{3}{|l|}{ Sub-total } & 906 & 181 \\
\hline \multirow{4}{*}{ Peripheral } & Jagrititol & HH, FGD, KII & 126 & 25 \\
\hline & Kalopool & $\mathrm{HH}$ & 6 & 1 \\
\hline & Palpakot & HH, FGD. KII & 30 & 6 \\
\hline & Ramhiti & $\mathrm{HH}, \mathrm{KII}, \mathrm{CS}$ & 126 & 25 \\
\hline \multicolumn{3}{|l|}{ Sub-total } & 288 & 57 \\
\hline \multicolumn{3}{|l|}{ TOTAL } & 1573 & 314 \\
\hline
\end{tabular}

Household survey (HH), Focus Group Discussion (FGD), Key Informant Interview (KII), case studies and informal conversations were key tools of data collection. Altogether 314 household were selected for the interview. FGDs were conducted at six different poverty pockets i.e. Panchayanghat, Balkhu, Gairigaun, Narayantol, Jagrititol and Palpakot; participated minimum 5 persons at Gairigaun to maximum 12 at Balkhu; representing male, female, from the different ethnic background and income level. Chairman of TolSudharSamittee, promoter and aged persons in the poverty clusters were taken as key informants. There were 11 key informants contacted and interviewed 
to collect information related to the livelihood and coping strategies of poor people in Kathmandu in the post-conflict phase. A set of checklist was prepared for discussion. Case Studies (CS) and informal conversation were also used to investigate the insightful information regarding the mobility, knowledge and livelihood. The conversation was conducted at work place and/or during the rest time or walking or waiting for work or at tea stall; and flagged the main points while talking to each other. Many informal conversations took place at Balkhu, Shantinagar, Panchayanghat, Shankhamul, Ramhiti, Bijayanagar, Shantinagar, Narayantol and Jagrititol.

\section{Results and discussion}

\section{Livelihood between conflict and post-conflict periods}

The conflict has an impact on the livelihood of the urban poor communities. Two-thirds of the households' respondent reported that their daily livelihood activities were hit by armed conflict in the past. Fear of tension and threat from other (political and ethnic) groups were profound among the conflict affected people and households. They were forced to donate or to join in the Maoist movement or spy against government or participate in the Maoist rallies and gatherings. Out of the total conflict affected households, nearly one-third was suffering from the fear of tension or threat. Low paid employment and loss of employment opportunities were also reported by almost onefifth. Out of the total affected, around 18\% households reported that they were affected because of the poor social security, which heightened social violence, looting and robbery (Table 2).

Table 2. Impact of armed conflict on livelihood (in percentage)

\begin{tabular}{|l|c|c|c|c|}
\hline \multirow{2}{*}{ Affects } & \multicolumn{3}{|c|}{ Zones } & \multirow{2}{*}{ Average } \\
\cline { 2 - 4 } & Central & Middle & Peripheral & \\
\hline Fear of Tension/Threat & 34.52 & 32.46 & 32.65 & 32.83 \\
\hline Low Wage Rate & 27.38 & 22.90 & 26.53 & 24.29 \\
\hline Loss of Employment Opportunities & 21.43 & 24.64 & 18.37 & 22.96 \\
\hline Poor Social Security & 16.67 & 17.97 & 21.43 & 18.40 \\
\hline Displacement & 0.00 & 0.87 & 0.00 & 0.57 \\
\hline Disturbing Child School & 0.00 & 0.58 & 0.00 & 0.38 \\
\hline Others & 0.00 & 0.58 & 1.02 & 0.57 \\
\hline Total & 100.00 & 100.00 & 100.00 & 100.00 \\
\hline
\end{tabular}

Source: Field Study, 2009. 
Kedar Dahal / The Geographical Journal of Nepal Vol. 10: 73-88, 2017

The impact among three zones of the study area is found to be different. Disturbance schooling for children, reduction in mobility due to restriction were also reported and this is found only in the middle and peripheral zone(Figure 3).

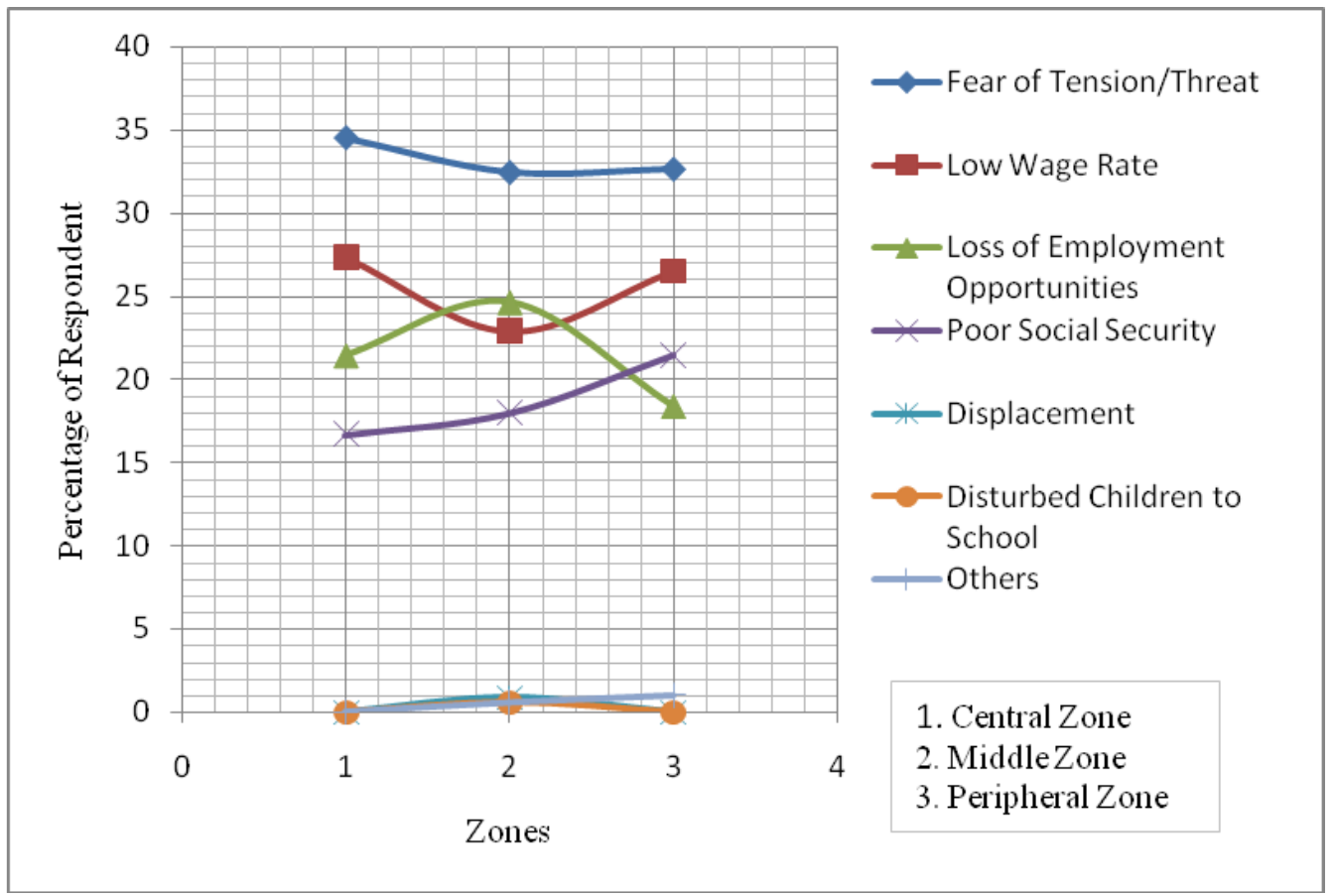

Figure 3. Impacts of armed conflict

The present study shows that livelihood options of poor urban communities changed in the conflict and post-conflict phase. In the post-conflict situation, people's involvement in the sectors like agriculture and livestock declined; whereas private and professional services, driving, and foreign employment have increased significantly. Case studies show that people engaged in small business (including mobile vending) have increased by $45 \%$ after the conflict. Similarly, private and professional services have been increased by $380 \%$ in the post-conflict period, followed by driving and fare collector and foreign employment. However, some of the activities, for example, government services, agriculture and livestock; and wage labour have decreased significantly during the same period. A very different picture is found in the government service sector, for example those who had a job in the government service before the conflict have not retained their jobs in the post-conflict phase which means that they lost their jobs due to conflict (Figure $4 \& 5$ ). 
Kedar Dahal / The Geographical Journal of Nepal Vol. 10: 73-88, 2017

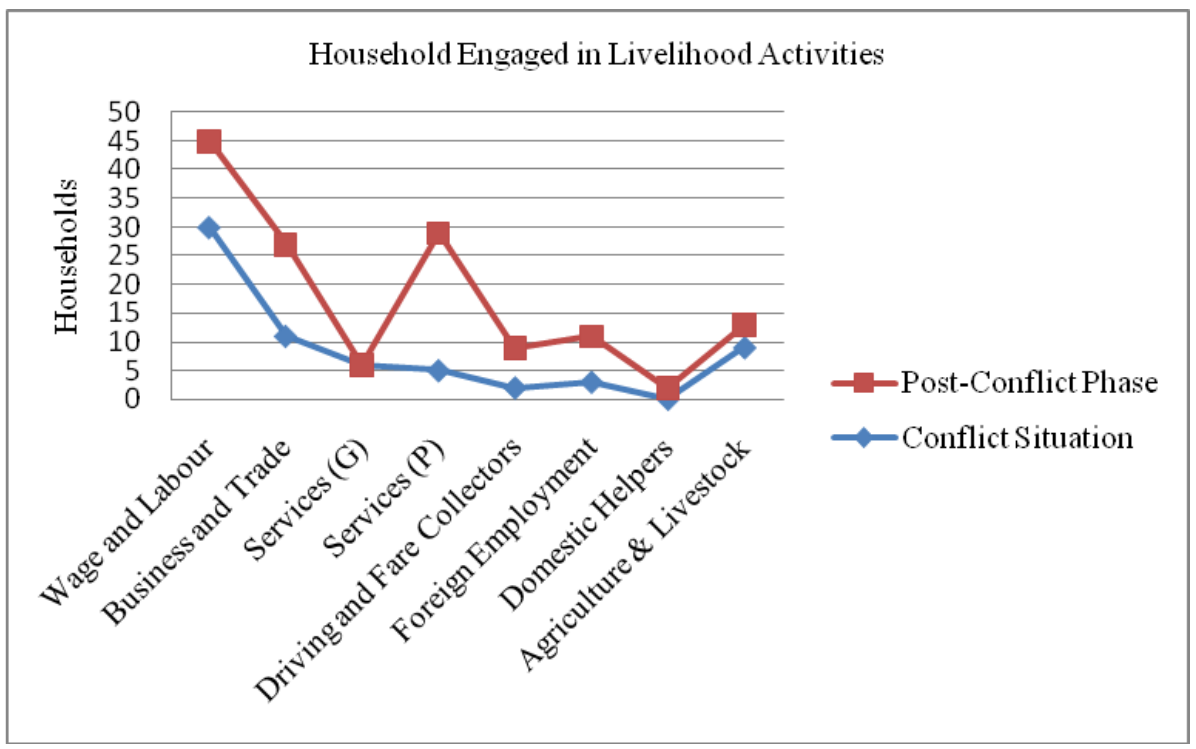

Figure 4. Household engaged in livelihood activities before and after conflict

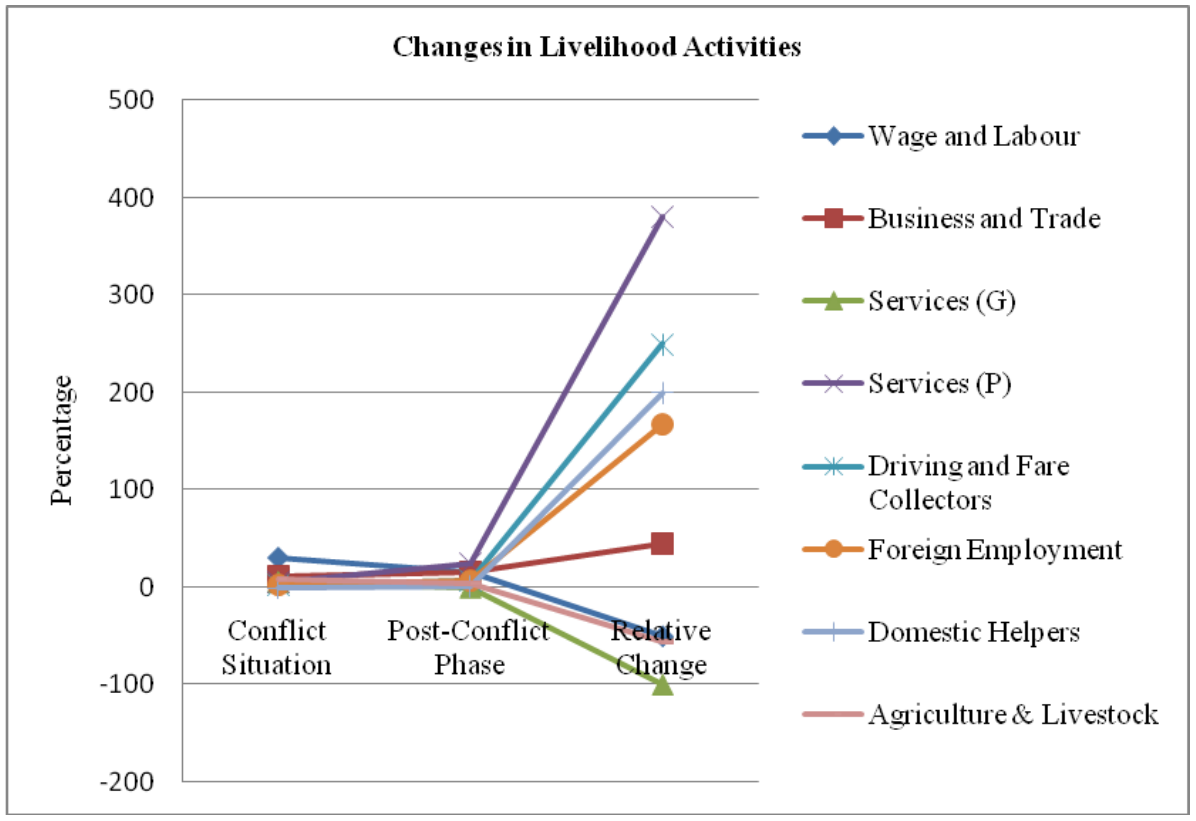

Figure 5. Changes in livelihood activities in conflict and post-conflict phase 
Four main causes are identified for changing livelihood in the post-conflict phase. These are:(i) many people involved in private and professional services are working safely and expanding their scope in the post-conflict;(ii) after Maoists joined in the main political process (after 2005), the communities have increased their mobility and level of confidence for bargaining and negotiation with (private) employer; (iii) increasing informal sector of urban economy attracted many young poor entering the informal labour market in Kathmandu. The formal service sector is highly competitive and the poor, therefore, are not able to enter this sector due to their low competitive strength e.g. poor level of education;and(iv) the feeling and perception of poor have changed in the post-conflict phase.

The feeling and perception of poor have changed in the post-conflict phase (Table 3). According to them, post-conflict situation is characterized by increase in various opportunities for livelihood security and many youths are entering into the labour market to secure their family income. People have enlarged their business and get more employment oppertunities in the private and professional service sectors and increasing the household/family income. Conversion to Christianity among the urban poor is rising in the post-conflict phase; and some of the households respondents feared from the increasing social evils, for example drug abuse and alcoholism among the poor youths.

Table 3. Perception of change in livelihood

\begin{tabular}{|l|l|}
\hline Conflict Situation & Post-conflict Situation \\
\hline $\begin{array}{l}\text { Fear and Threat } \\
\text { (in Common life) }\end{array}$ & $\begin{array}{l}\text { Increasing feelings of safety. Post-conflict phase is characterized } \\
\text { by safety business and livelihood activities. The phase is very } \\
\text { easy to look potential opportunities and work in the urban area. }\end{array}$ \\
\hline $\begin{array}{l}\text { Single earner with no } \\
\text { secure income sources }\end{array}$ & $\begin{array}{l}\text { The level of household income increased in the post-conflict } \\
\text { phase. Multiple income sources of family reported to be the } \\
\text { highest in this phase, such as wage labour and petty trade or } \\
\text { vendor. }\end{array}$ \\
\hline $\begin{array}{l}\text { Less Employment } \\
\text { Wpportunity and Low }\end{array}$ & $\begin{array}{l}\text { Post-conflict is also characterized by increasing employment } \\
\text { opportunities for the poor in urban informal sectors. }\end{array}$ \\
\hline $\begin{array}{l}\text { Small scale and less } \\
\text { profitable business e.g. } \\
\text { wage labour and livestock }\end{array}$ & $\begin{array}{l}\text { Enlarge and diversification of the size of business, e.g. vendor } \\
\text { business }\end{array}$ \\
\hline High discrimination & $\begin{array}{l}\text { Discrimination is still reported in the community and } \\
\text { neighborhoods. }\end{array}$ \\
\hline $\begin{array}{l}\text { Job loss and social } \\
\text { insecuritye.g. army and } \\
\text { security personnel lost } \\
\text { their job in the conflict and } \\
\text { insurgency period }\end{array}$ & $\begin{array}{l}\text { Opportunity of other employment in the market; increasing } \\
\text { religious activities and programmes e.g. Christian in the post- } \\
\text { conflict, and improved social security. }\end{array}$ \\
\hline
\end{tabular}

Source: Field Survey, 2009 and 2013 
Wage rate is found to be different before and after the conflict. During the conflict situation, wage rate for male was reported to be only NRs 150 to NRs200/day, and NRs 100-125/day for female. In the post-conflict, the wage rate increased by $50 \%$ in the initial years and increased by $150 \%$ in 2013 for male and almost double for female. Nonetheless, the skilled workers, for example, carpenters, masons, cement plasters, have received $25-50 \%$ higher wage rate than the skill-less worker. Skilled workers get NRs $700-800$ /day (FGD with a group of wage labour, July 2013). Though inflation is one of the reasons for such increase wage rate but the empowerment of the communities and increasing capacity of bargaining and negotiation after the conflict are other important causes of increasing wage rate in the post-conflict period in the urban area.

\section{Livelihood insecurity and coping strategies}

Urban labour market in Kathmandu is highly diversified and competitive. In the light of current social, ethnic and regional disturbances, the situation does not appear to become favourable for urban poor. Most of the dwellers are unskilled and illiterate; therefore, job opportunities are also unreliable, irregular and subject to high seasonal variation. Most people that were interviewed have many difficulties in securing sustainable sources of income. Change in the working trips and food habits are important coping strategies. In addition, mutual cooperation, increased social networking, borrowing and loan are other coping strategies when the livelihood is threatened. Number of children involved in activities, such as, collecting garbage as heating material and shelter (which are time-consuming and in hibit regular school attendance) increased, thereby contributing to overall decrease in educational level. Some of the children are able to trade-off successfully between school and work. They visit school in the mornings and pursue work in the afternoon, thereby keeping up hopes of a better future for themselves and their families (Dahal\& Sapkota, 2005). Diversification of sources of income help to decrease food insecurity.

In the context of constant cash-flow problems, taking loans and borrowing are often practised among the poor to meet daily requirements, resulting in high levels of indebtedness. Access to loans from the local saving and credit groups and cooperatives managed by the local community often put them into the pressure for paying back with negotiable interest rate in the given time period. Therefore, borrowing from the close or immediate neighbors or relatives is often practised in the community which is a most important strategy of livelihood. Elderly and disabled are generally susceptible to loss of income and indebtedness. 
In general, tendency of our family system, women and daughters often are the ones who eat last, and eat what has been left by the male household members. During the field work, a girl expressed her views as "there is never enough to eat for me and frequently, at night I am dreaming of food which I have eaten". This indicates that in the case of urban poor, most of the female members are under nourished.

Both loss of income and food insecurity have negative consequences on physical and mental wellbeing and investing money in their health care that may put livelihood of household/family for further risk and insecurity. Nearly one percent $(0.98 \%)$ family membersare suffering from the chronic diseases especially Asthma and TB and nearly $4 \%$ population is either helplessness or has disabilities in the poverty pockets whose livelihood is more vulnerable. Sometimes children are the sole bread winners of the family, particularly when their parents have reached an age or face health problems that reduced to mobility for work. It has also been noted that many households do not attempt to seek professional medical treatment. People directly approach pharmacies and seek advice about their problems in order to avoid expensive consultancy fees of clinics or doctors.

Health hazard in poverty pocket is highly related to poor housing condition, lack of sanitation, poor water supply or inadequate waste and sewage disposal as well as polluted river water. Many houses of the poverty pockets such as Inyatol, Ramghat, Panchayanghat, Balkhu, Shankhamul, Shantinagar, Bijayanagar, Gairigaun and Jagrititol are built on the bank of Bagmati River; dumping site (Balkhu, Panchayanghat), and shrine area (e.g. Shankhamul) where health hazard is observed and susceptible to diseases and illness. Poor housing, water logging, dumping site in the proximity of their dwelling unit, narrow lanes between dwellings (in Balkhu and Shantinagar), are collectively creating high health risk. Some of the key voices of poor communities living in Balkhu area are as follows:

"Rich people getting poor while living in the poverty pocket. Culture of poverty makes them unhappy and vulnerable". (Daniel Pun, a social activist).

"Sir, could you imagine, how you feel, living in the Jhupadi of plastic-sheet and thatch in the winter season and on the cold floor....?" (A woman at Balkhu community).

Poor are getting poorer. We can generate cash from the casual work but that will not available in all days and in all season; in many cases, contractor/ sub-contractor will not pay our wage in time, that makes us more vulnerable and poor,". ....?"

(A wage labour at Balkhu community). 


\section{Perceptions of poverty and the coping strategies}

There are differences and inequalities among the urban poor in the poverty pockets. They are facing different situations, experiences, and levels of livelihood security; largely defined by their household histories, household structures and composition, and by the types of works that they are able to access. In this study, different criteria were used to differentiate varying degrees of poor condition ${ }^{2}$. Finally, urban poor have been grouped into three broad categories: Poorest, poorer and poor; which is appropriate measures for understanding their situation (Schutte, 2006); and coping strategies adopted by these groups vary which is discussed below.

- Poorest families/household: Poorest families are those whose family income NRs 200/day or less, no saving, high dependency ratio (e.g. $75 \%$ or more), beggars, no electricity, no telephone and television, use kerosene or firewood for cooking, temporary (Kachhi) dwelling unit, no window and one storey, family at risk or threats, conflict affected, no properties at origin, no fridge or own vehicle, single earner, no male income earner and cannot eat properly every day.During the deficit or famine period, these people are involved in the distant wage labour, collection of garbage and begging activities. Similarly; change in food habit, engaged in small scale street shop, low paid labour, borrowing and loans are other coping strategies of this group.

- Poorer families/household: Those who can eat properly but cannot afford other basic necessities (clothes, housing etc.), headed by people with sickness and cannot work properly, have to take care of disabled members, and who have more regular but insecure work opportunities. Wage labour, vender shop and loan are their main coping strategies. Social networks and seeking employment in the private company are their other coping strategies.

- Poor families/household: Less poor families are those who have regular income, whose family income NRs 500 or more/day, daily saving amount NRs 200 or more, have multiple income sources, able to access credit from micro-finance institution, low dependency ratio (e.g. $25 \%$ or less), can eat properly every day, electricity connection, having telephone or mobile phone, having television, use LPG gas for cooking, semi-permanent or permanent dwelling, three or more window two or more story, family not at risk or threats, not conflict affected, properties at origin, fridge and own vehicle (motorcycle).These people are adopting coping strategies such as involvement in the vender shop, livestock rearing, seeking mutual cooperation and 
Kedar Dahal / The Geographical Journal of Nepal Vol. 10: 73-88, 2017

social networking. Seeking jobs in the private and professional institutions, and borrowing loan are other coping strategies of this group.

The present study found that only $37 \%$ of the families are poorest. Peripheral zone has only $16 \%$ of poorest families compared to central and middle zone. About $36 \%$ families are found poor and most of them are in peripheral zone (51\%) (Table 4).

Table 4. Percentage of households/families poor

\begin{tabular}{|l|l|l|l|l|}
\hline \multirow{2}{*}{ Degree of poor } & \multicolumn{3}{|c|}{ Zones } & \multirow{2}{*}{ Average } \\
\cline { 2 - 4 } & Central & Middle & Peripheral & \\
\hline Poorest & 43.42 & 40.66 & 15.79 & 36.83 \\
\hline Poorer & 30.36 & 23.63 & 33.33 & 26.48 \\
\hline Poor & 26.31 & 35.71 & 50.88 & 36.19 \\
\hline \multirow{2}{*}{ Total } & 100.00 & 100.00 & 100.00 & 100.00 \\
& $(\mathrm{~N}=76)$ & $(\mathrm{N}=181)$ & $(\mathrm{N}=57)$ & $(\mathrm{N}=314)$ \\
\hline
\end{tabular}

Source: Field Study, 2009

Families, who are not falling in poorest or poor groups, are considered a poorer group. In this study more than $26 \%$ families are reported to be in poorer group. This study shows that poor families are highly exposed to their own business or foreign employment or skilled and highly paid work; while poorest have less exposure to wage labour, poor skill and low paid areas; subsequently are of having poor health and sanitary condition. A significant test shows that degrees of poverty (e.g. poorest, poorer and poor) depend on location $\left(\chi^{2}=15.88\right.$ at 0.05 significant level). Poorest group is found in central and middle zone whereas; poor is mostly in the peripheral zone of the metropolitan city.Wage/labour and vendor shops and services are the main livelihood activities in the central and middle zone; whereas, private and professional services and vendor trade/business are important sectors of employment in the peripheral zone.

\section{Livelihood risk}

More than two-third families/household still perceive a kind of risk or threat; and most of them are in the middle zone. For the purpose of analysis, all risks are grouped into six categories (Figure 6). Among them political threat and environmental risk are severe than others. It also indicates that the environmental risk is profound in center and middle zone and less in peripheral zone; whereas social threats, including communal discrimination, is relatively high in peripheral and middle zones. Though, people living 
in the poverty pockets have adopted different coping measures, these measures are not free from risk in the future.

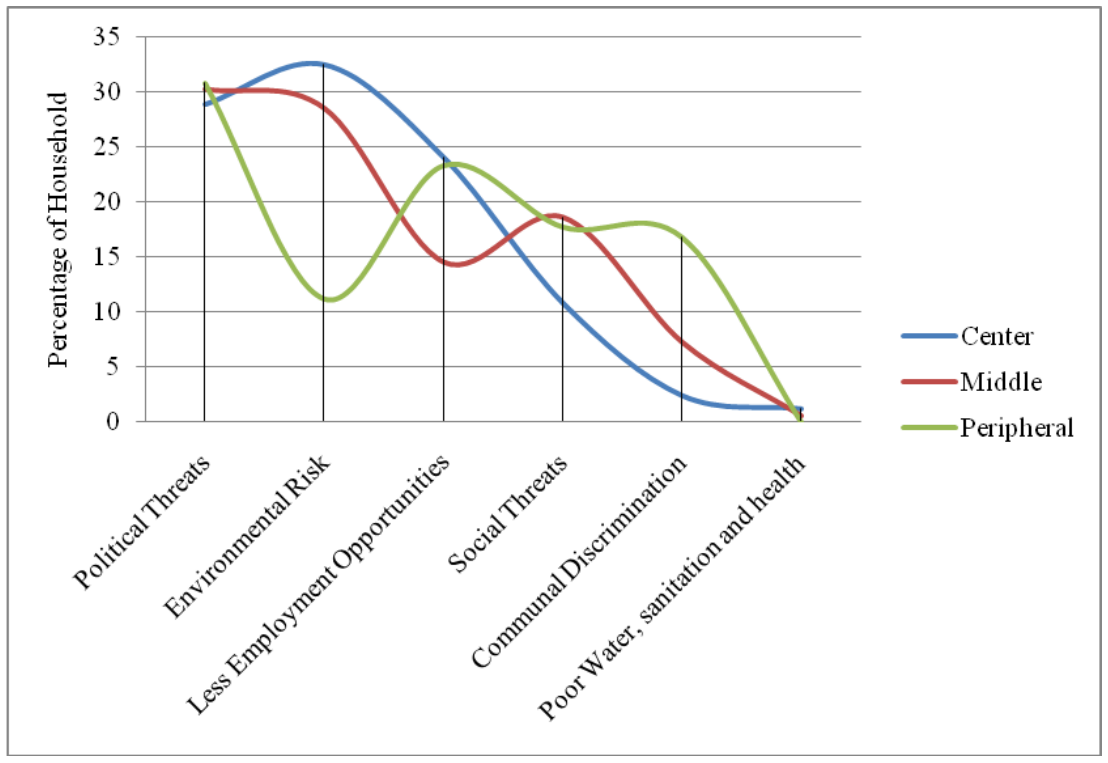

Figure 6. Household under risk/threats

\section{Conclusion}

In the post-conflict phase, variety of livelihood strategies are adopted by the urban poor.Private and professional services, driving and foreign employment are priority areas of interest of the poor youths in the post-conflict phase. They have changed their livelihood pattern and way of living in urban area through expanding their employment opportunities. Micro-saving and credit activities, social networks are encouraging them to increase their occupational mobility. Those families who are involved in the activities, such as, wage/labour or domestic helpers or agriculture and livestock are the poorest. They have weak socio-economic-political networks, suffering from the conflict and lack of health and education.Coping strategies such as involvement in the vender shop, livestock rearing, mutual cooperation, social networking borrowing and loan are adopted by poor class. Poorest group is mostly found in central and middle zones whereas; poor is in the peripheral zone of the metropolitan city.However, a decade long armed conflict also explores opportunities for maintaining social tie, reducing discrimination and makes people more powerful in the decision making process that has made livelihood easier than earlier. 


\section{Notes:}

Mitlin Diana (2004) used the term "Pockets of Poverty" for the clusters or poor concentration location in the urban area. According to Diana " there may be serious "Pockets of Poverty" within the urban area, that urban poverty may be increasing and that inequality may be higher in urban areas than in rural areas"

Twenty-one indicators are: level of household income, saving amount, dependency ratio, beggar, electricity connection, pipe water available, TV and telephone use, gas stoves and cylinder use for cooking, fridge use, types of roof, types of wall materials, number of building storey, available of window, number of room, access to health and school, conflict affected, $\mathrm{HH}$ at risk and threats, properties at origin and enough to food. All these indicators were grouped into eight main criteria of evaluation. These are: household income and expenditure, dependency ratio, access to physical facilities ( e.g. electricity, telephone, TV, fridge, vehicle and gas stove/cylinder), types of house, risk and threats at present location, conflict affected household/families, access to organization (saving/credit institution, cooperatives, NGOs, INGOs, CBOs, and properties at origin.

\section{References:}

B.K., Nirmal K., Shrestha, R.,Acharya, S.G., \& Ansari, A. (2009). Maoist conflict, community forestry and livelihoods: Pro-poor innovations in forest management in Nepal. Journal of Forest and Livelihood.8 (2), pp.93-100.

Dahal, K. (2012). Poor Communities and Livelihood in Urban Context, Kathmandu Metropolitan City, Nepal [Unpublished PhD. Thesis]. University of Delhi, New Delhi.

Dahal, K., \& Sapkota, K. (2005). Sustainable livelihood of urban poor, case of Kathmandu Metropolitan City.[Unpublished Research Report], Research Division, Tribhuvan University,Kathmandu.

Diana, Miltin. (2004).Understanding urban poverty; what the poverty reduction strategy papers tell us. London: IIED. Retrieved from http://www.sdinet.co.za/static/ pdf/understanding_urban_poverty_mitlin.pdf

Harpham, T.,Tim L., \& Patrick V. (Eds.) (1988). In the shadow of the city.Community health and urban poor.Oxford University Press.

Pain, Adam, \& Lautze, Sue. (2002). Addressing Livelihoods in Afghanistan (Issues Papers Series). Kabul: Afghanistan Research and Evaluation Unit (AREU). Retrieved from http://areu.org.af/wp-content/uploads/2015/12/206EAddressing-Livelihoods-IP.print_.pdf 
Kedar Dahal / The Geographical Journal of Nepal Vol. 10: 73-88, 2017

Schafer, Jessica. (2002). Supporting livelihoods in situations of chronic conflict and political instability: overview of conceptual issues(Working Paper 183). London: Overseas Development Institute.Retrieved from http://www.odi.org. uk/resources/details.asp?id=1995\&title=livelihoods-situation-chronic-conflictpolitical-instability-overview-conceptual-issues

Schutte, Stefan. (2006). Poor, poorer, poorest: urban livelihoods and vulnerability in Mazar-i-Sharif (Case Study Series). Kabul: Afghanistan Research and Evaluation Unit (AREU). Retrieved from

www.geo.fuberlin.de/geog/fachrichtungen/anthrogeog/zelf/median/downloaded/ schuette

Seddon, David, \& Karim, Hussein.(2002). The consequences of conflict: livelihoods and development in Nepal(Working Paper 185). London: Overseas Development Institute.

Sharma, Pitamber. (2003). Urbanization and development. Population Monograph of Nepal.Volume I, pp. 375-412. Kathmandu: Central Bureau of Statistics, Government of Nepal.

Sirkeci, Ibrahim. (2009). Transportation mobility and conflict. Migration Letters6(1), pp1-14.

Upreti, Bishnu Raj. (2004). A Decade of Armed Conflict and Livelihood Insecurity in Nepal.Retrieved from http://www.wilsoncenter.org/events/docs/upreti_paper.pdf 